\section{European Integration}

Studies / 2018, No. 12

Faculty of Social Sciences, Arts and Humanities Institute of Europe, Kaunas University of Technology

This annual journal is dealing with interdisciplinary field of European Union law, economics, policies and history research with the aim to form the common ground for discussion, exchange of ideas and to foster the integrated research concerned with problems and actualities of European integration processes.

\section{Designer}

\section{EVELINA GARLIAUSKIENE}

\section{Correspondence}

Editorial Board of European Integration Studies

Mickevicius str. 37 ,

LT-44244 Kaunas, Lithuania

Phone +370 61556233

E-mail rasa.daugeliene@ktu.lt

Web Site in OJS (Open Journal System): www.eis.ktu.lt

The journal European Integration

Studies in print since 2007

(C) Kaunas University of Technology, 2018

(C) Publishing House “Technologija“ (Design), 2018

Authors hold the responsibility for the Journal language.

Editors hold the responsibility for the Journal content
Editor-in-Chief

Assoc. prof. dr. RASA DAUGÉLIENÉ

Kaunas University of Technology, Lithuania

International Editorial Board

Prof. FEDERIGA BINDI, University of Rome, Italy, federiga.bindi@EUl.eu Assoc. Prof. Dr. ALEKSANDRA BOROWICZ, University of Gdansk, Poland, aleksandra.borowicz@ug.edu.pl

Assoc. Prof. Dr. JURGITA BRUNECKIENĖ, Kaunas University of Technology, Lithuania, jurgita.bruneckiene@ktu.lt

Dr. RICHARD CADDELL, Utrecht University, Netherlands, j.r.caddell@uu.nl Prof. MARTIN DANGERFIELD, University of Wolverhampton, United Kingdom, M.Dangerfield@wlv.ac.uk

Assoc. Prof. Dr. JOLITA GREBLIKAITĖ, Aleksandras Stulginskis University, Lithuania, jolita19@gmail.com

Assoc. Prof. Dr. NATALJA GURVITS, Tallin University of Technology, Estonia, natalja. gurvits@ttu.ee

Prof. Dr. JARI KAIVO-OJA, Finland Futures Research Centre, Turku School of Economics, University of Turku, Finland, jari.kaivo-oja@utu.fi

Prof. Dr. AKSEL KIRCH, School of Economics and Business Administration, Tallinn University of Technology, Estonia, Aksel.Kirch@ttu.ee

Assoc. Prof. Dr. AINIUS LAŠAS, Kaunas University of Technology, Lithuania, ainius. lasas@ktu.lt

Prof. Dr. PAWEL MLODKOWSKI, School of International Liberal Arts, Miyazaki International College, Miyazaki, Japan, pawel.mlodkowski@gmail.com

Assoc. Prof. Dr. JANIS PRIEDE, University of Latvia, Latvia, janis.priede@lu.lv Prof. Dr. GAZMEND QARRAJ, University of Prishtina, Kosovo, gazmendqorraj@ yahoo.com

Assoc. Prof. Dr. RIMANTAS RAULECKAS, Kaunas University of Technology, Lithuania, rimantas.rauleckas@ktu.lt

Prof. Habil. Dr. BAIBA RIVŽA, Latvia University of Agriculture, Latvia, baiba.rivza@llu.lv Assoc. Prof. Dr. LOREDANA SIMIONOV, University Alexandru loan Cuza in laşi, Romania, lori.simionov@gmail.com

Assoc. Prof. Dr. JOLITA SINKIENĖ, Kaunas University of Technology, Lithuania, jolita.sinkiene@ktu.lt

Prof. BIRUTA SLOKA, University of Latvia, Latvia, biruta.sloka@lu.lvProf. Dr. Jari Stenvall, University of Tampere, Finland, Jari.Stenvall@uta.fi

Prof. Dr. JARI STENVALL, University of Tampere, Finland, Jari.Stenvall@uta.fi

Assoc. Prof. Dr. JOANA STRYJEK, SGH Warsaw School of Economics, Poland, jstryj@sgh.waw.pl

Assoc. Prof. Dr. JURGITA ŠIUGŽDINIENĖ, Kaunas University of Technology, Lithuania, jurgita.siugzdiniene@ktu.lt

Prof. Habil. Dr. HELENA TENDERA-WLASZCZUK, Cracow University of Economics, Poland, tendera@uek.krakow.pl

Prof. Dr. STANISLAW UMINSKI, University of Gdansk, Research Centre on

European Integration, Poland, uminski@univ.gda.pl

Prof. Dr. Phil. VELGA VEVERE, The University College of Economics and Culture, Latvia, velga.vevere@gmail.com

Prof. Dr. Habil. KRZYSZTOF WACH, Cracow University of Economics, Poland, wachk@uek.krakow.pl

Assoc. Prof. Dr. MAŁGORZATA ZAJACZKOWSKI, Warsaw School of Economics, Poland, mgraci@sgh.waw.pl

Dr. Oerc. Assoc. Prof. ROSITA ZVIRGZDINA, Turiba University, Latvia, rosita@turiba.lv 


\section{Editorial Note}

Since 2002, Institute of Europe of Faculty of Social Sciences, Arts and Humanities (Kaunas University of Technology) prepares and publishes scientific works under the theme of European Processes in the field of politics, economics, law and cultural dimensions. Starting 2007 year the journal has got an ISSN code. At the present the annual scientific journal European Integration Studies (ISSN 1822-8402) is published once a year (in September).

The papers published in Journal are abstracted and indexed by International Databases: EBSCO (Central \& Eastern European Academic Source Database Coverage List), EBSCO (Business Source Complete), EBSCO Discovery Service (EDS), DOAJ (Directory of Open Access Journals), EconBib (Economics Bibliography) and Emerging Sources Citation Index (ESCl, New Edition of Web of Science). Journals in ESCl have passed an initial editorial evaluation and can continue to be considered for inclusion in products such as $\mathrm{SCIE}, \mathrm{SSCl}$, and $\mathrm{AHCl}$, which have rigorous evaluation processes and selection criteria. Papers published in the European Integration Studies undergone a formal process of double blind peer review by two appointed external reviewers.

The main objective of the journal is to analyse problems and actualities considering European integration processes. The articles are brought under the three main themes. These are Social Evolution of Europe, Economics of European Union as well as Managerial Aspects of European Integration.

It is believe that the articles included in the journal, being selected and reviewed, are of high scientific quality were actual scientific problems are solved, deserve a wide distribution. Editors hope that presented new scientific ideas and ways of problems solving will help to develop research not only for academicians and students but and for a wide representatives of society which seek to improve their knowledge in European Integration.

In conclusion, editors would like to thank all authors of the articles for their willingness to share their ideas with others.

Rasa Daugèlienè 